\title{
Implementation of the Bayes theorem method for identifying diseases of children under five
}

\author{
Macro Ramadhani ${ }^{1)}$, Volvo Sihombing ${ }^{2} *$, Masrizal $^{3)}$ \\ 1) 2) 3) Labuhan Batu University, Indonesia \\ 1) marcokaro2@gmail.com, ${ }^{2)}$ volvolumbantoruan@gmail.com, ${ }^{3)}$ masrizal120405@gmail.com
}

Submitted: Mar 16, 2021 | Received: 5 Apr, 2021 | Published: 5 Apr, 2021

\begin{abstract}
Disease is very susceptible to occur in children under five because the immune system in children under five has not been fully developed. Lack of knowledge about the diseases of children under five and the symptoms they experience makes parents fearful. The lack of knowledge of children's diseases from experts can result in delayed treatment. Problems that occur can be overcome by utilizing artificial intelligence technology. One of the artificial intelligence technologies is an expert system. Information needs very quickly from an expert to deal with problems or diseases of children under five that are expected by parents or society. So that is what drives the development of a software application, namely an expert system for the identification of diseases of children under five. An expert system for the identification of toddlers' diseases is made as a tool to diagnose diseases experienced by toddlers by using the symptoms experienced by toddlers as a tool to detect diseases experienced by children under five. The system can identify 5 types of disease with 23 symptoms of disease. This expert system uses the development method of problem identification, system design, implementation and testing. Inference in this expert system uses the Bayes theorem method. This system is built with Visual Basic and Microsoft Access as the database. The results of consulting tests with this system show that the system is able to determine the disease along with the initial treatment and treatment solutions that must be carried out, based on the symptoms previously selected by the user.
\end{abstract}

Keywords: Bayes Theorem, Expert System, Microsoft Access, Toddler Disease, Visual Basic

\section{INTRODUCTION}

Toddlers are very susceptible to disease, caused by the immune system in the toddler's body which is not yet fully awakened and a lack of knowledge of the symptoms of a disease that frightens parents. Knowledge of the symptoms of a child's disease is very important because parents will be able to take early action so that it does not reach a severe stage. The knowledge needed is information from a child health expert. The lack of knowledge of children's diseases from experts can result in delayed treatment. Problems that occur can be overcome by implementing artificial intelligence, including expert systems.

Research (Sianturi, 2019) explained that the AI expert system is defined as computer science that can help human work, in this study the results showed that the expert system can be implemented properly and the expert system can provide a solution to a disease that is found. (Dewi et al., 2015)For parents who have children under five, it is still found that many parents are confused when their toddler is sick because there are still few general practitioners who directly treat diseases in children under five at this time in terms of working time.(Fricles Ariwisanto Sianturi, 2019). Thus, this research aims to create an expert system application that can be used by the community, especially parents who have children under five, to identify diseases of children under five by applying the Bayes method.(Aji et al., 2018)An expert system for the identification of toddlers' diseases is made as a tool to diagnose diseases experienced by toddlers by using the symptoms experienced by toddlers as a tool to detect diseases experienced by children under five. The system can identify 5 types of disease with 23 symptoms of disease.(Aini et al., 2017)The expert system studied used the development method of problem identification, system design, implementation, and testing. Inference in this expert system uses the Bayes theorem method. The results of research conducted with this system indicate that the system is able to determine the disease along with the initial treatment and treatment solutions that must be carried out, based on the symptoms previously selected by the user. 


\section{Expert system}

\section{LITERATURE REVIEW}

Expert systems are defined as well(Ramadan \& Pane, 2018) Knowledge Based System, which is defined as a computer application that has the goal of helping decision making or solving in a particular field(Gunawan \& Wardoyo, 2018). According to(Sinaga et al., 2018) that the benefits of an expert system are:

1. Expert systems can work faster than humans.

2. The quality level of suggestions is very consistent and can reduce problems.

3. Capturing human expertise

4. Make it easier for expert knowledge

5. Can be used to support the training of a test.

\section{Bayes' Theorem method}

According to (Ramadan, 2018) explains that the Bayes theorem is a method used to calculate the uncertainty of data into definite data by comparing the yes and no data.

The Bayes method has a probability that the Bayes method is used as one way to overcome uncertainty with the Bayes formula(Harijanto \& Latif, 2016),(Pramudia \& Nugroho, 2017)

$$
P(H \mid E)=\frac{P(E \mid H) \cdot P(H)}{P(E)}
$$

Information :

$\mathrm{P}(\mathrm{H} \mid \mathrm{E})=$ probability of hypothesis $\mathrm{H}$ if given evidence $\mathrm{E}$

$\mathrm{P}(\mathrm{E} \mid \mathrm{H})=$ probability of the emergence of evidence $\mathrm{E}$ if the hypothesis is known $\mathrm{H}$

$\mathrm{P}(\mathrm{H}) \quad=$ probability $\mathrm{H}$ without containing any evidence

$\mathrm{P}(\mathrm{E}) \quad=$ probability of evidence $\mathrm{E}$

Based on previous research, there are several results found using the Bayes Theorem method.

Research (Ramadan, 2019)with the title Application of Comparison of Bayes Theorem with Euclidean Probability in Dermatic Bacterial Diagnosis, obtaining the results of the analysis with the Bayes Bayes theorem by using a comparison of diagnostic values and exponential techniques, it can be obtained the comparison of the diagnosis value on the Euclidean Probability of 0.74 or $74 \%$ while the Bayes Theorem produces the diagnosis value of 0.51 or $51 \%$ both resulted in the conclusion of the diagnosis, namely the type of Impetigo disease. Then for the Euclidean Probability exponential technique, it gets a priority value of 0.86 or $86 \%$ greater than the Bayes Theorem which gets a priority value of 0.71 or $71 \%$, as well as in the research conducted.(Syahputra et al., 2017) conclude From the calculation process using the Bayes method, it can be seen that the diagnosis of aplastic anemia with a confidence value of 0.3237 or $32.38 \%$

\section{METHOD}

The stages of the research method used in conducting research consist of five stages including:

1. Problem Identification, is the initial stage in carrying out research with the aim of formulating problems by observing.

2. Data collection, the steps taken to collect the data needed to be used in testing with the method used, besides that, the data collection stages are carried out by reading references in the form of scientific journals or ebooks as the reference language in supporting research that is will be done.

3. System Design, this stage is designing or designing a system with Visual Basic applications with Microsoft Access databases in accordance with the kebuthan of the problem.

4. Implementation, this stage is carried out by implementing the Bayes Terorema method which has been analyzed by calculations with an application made in accordance with the symptoms obtained and the disease.

1. Disease Data(Sasangka \& Witanti, 2019)

Obtained some disease data from children under five which is used for calculation analysis with the method used.

Table 1

Disease Data

\begin{tabular}{ccc}
\hline \hline NO & $\begin{array}{c}\text { Code } \\
\text { Disease }\end{array}$ & $\begin{array}{c}\text { Name of } \\
\text { Disease }\end{array}$ \\
\hline 1 & P01 & Ispa
\end{tabular}




\begin{tabular}{|c|c|c|}
\hline 2 & P02 & Measles \\
\hline 3 & $\mathrm{P} 03$ & Ear infection \\
\hline 4 & P04 & $\begin{array}{l}\text { Whooping } \\
\text { cough }\end{array}$ \\
\hline 5 & P05 & Chicken pox \\
\hline
\end{tabular}

2. Symptom Data(Murni \& Riandari, 2018)

There are several symptoms of disease with probability values as follows:

Table 2

Disease Symptoms

\begin{tabular}{clc}
\hline $\begin{array}{c}\text { Code } \\
\text { Sym } \\
\text { ptom } \\
\text { s }\end{array}$ & What is the name & $\begin{array}{c}\text { Score } \\
\text { Proba } \\
\text { bility }\end{array}$ \\
\hline G01 & Sneezing frequently & 0.1 \\
G02 & Runny and stuffy nose & 0.4 \\
G03 & The lungs feel slow & 0.6 \\
G04 & Cough cough and sore throat & 0.4 \\
G05 & Often feel tired & 0.1 \\
G06 & Body aches & 0.3 \\
G07 & Red eye & 0.4 \\
G08 & Eyes sensitive to light & 0.1 \\
G09 & Nasal congestion & 0.6 \\
G10 & Fever & 0.2 \\
G11 & Grayish white patches on the & 0.1 \\
G12 & mouth and throat & 0.8 \\
G13 & Hearing disorders & 0.5 \\
G14 & Ear pulling & 0.1 \\
G15 & Insomnia & 0.6 \\
G16 & Runny nose & 0.2 \\
G17 & Nasal congestion & 0.2 \\
G18 & Red and watery eyes & 0.4 \\
G19 & Cough & 0.2 \\
G20 & Fever & 0.4 \\
G21 & Stomach ache & 0.2 \\
G22 & Sore throat & 0.1 \\
G23 & Mild nausea & 0.4 \\
\hline
\end{tabular}

5. Testing, this stage is the final stage to test the level of accuracy of the analysis carried out on the suitability of the system by means of testing directly identifying one of the patients who has children under five.(Muslim, 2015).

An overview of the stages of the research method can be seen in the image below.

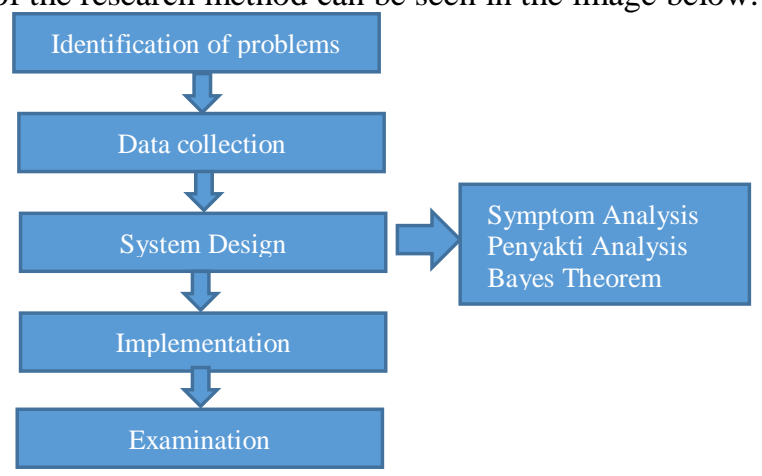

Fig 1. Research Stages 


\section{RESULTS}

From the results of the consultation carried out, it was found that the symptoms experienced by toddlers were as follows:

1. $\mathrm{G} 01=$ Frequent sneezing $(0.1)$

2. $\mathrm{G} 02=$ Nasal congestion and runny $(0.4)$

3. G03 = Lung feels slow (0.6)

4. G04 = cough - cough and sore throat $(0.4)$

5. $\mathrm{G} 05=$ Often feel tired $(0.1)$

6. G06 = Body feels sick $(0.3)$

7. $\mathrm{G} 14=$ Pulling the ear $(0,1)$

$$
\begin{aligned}
& \mathrm{G} 01=0.1=\mathrm{P}(\mathrm{E} \mid) \mathrm{G} 05=0.1=\mathrm{P}(\mathrm{E} \mid) \mathrm{H}_{1} \mathrm{H}_{5} \\
& \mathrm{G} 02=0.4=\mathrm{P}(\mathrm{E} \mid) \mathrm{G} 06=0.3=\mathrm{P}(\mathrm{E} \mid) \mathrm{H}_{2} \mathrm{H}_{6} \\
& \mathrm{G} 03=0.6=\mathrm{P}(\mathrm{E} \mid) \mathrm{G} 14=0.1=\mathrm{P}(\mathrm{E} \mid) \mathrm{H}_{3} \mathrm{H}_{7} \\
& \mathrm{G} 04=0.4=\mathrm{P}(\mathrm{E} \mid) \mathrm{H}_{4}
\end{aligned}
$$

To find the universe, it can be added from the above hypothesis

$\sum_{i=1}^{n}=\mathrm{G0} 1+\mathrm{G} 02+\mathrm{G} 03+\mathrm{G} 04+\mathrm{G} 05+\mathrm{G} 06+\mathrm{G} 14$

$$
=0.1+04+0.6+0.4+0.1+0.3+0.1
$$

$=2$

After obtaining the above summations, then calculating the probability value of the hypothesis $\mathrm{H}$ without looking at any evidence, which is as follows:

$$
\begin{aligned}
& \mathrm{P}()==0.05 \mathrm{H}_{1} \frac{\mathrm{P}\left(\mathrm{E} \mid \mathrm{H}_{1}\right)}{\sum_{\mathrm{i}=1}^{\mathrm{n}} \mathrm{P}\left(\mathrm{E} \mid \mathrm{H}_{1}\right)} \frac{0,1}{2} \\
& \mathrm{P}()==0.2 \mathrm{H}_{2} \frac{\mathrm{P}\left(\mathrm{E} \mid \mathrm{H}_{2}\right)}{\sum_{\mathrm{i}=1}^{\mathrm{P}} \mathrm{P}\left(\mathrm{E} \mid \mathrm{H}_{2}\right)} \frac{0,4}{2} \\
& \mathrm{P}()==0.3 \mathrm{H}_{3} \frac{\mathrm{P}\left(\mathrm{E} \mid \mathrm{H}_{3}\right)}{\sum_{\mathrm{i}=1}^{\mathrm{n}} \mathrm{P}\left(\mathrm{E} \mid \mathrm{H}_{3}\right)} \frac{0,6}{2} \\
& \mathrm{P}()==0.2 \mathrm{H}_{4} \frac{\mathrm{P}\left(\mathrm{E} \mid \mathrm{H}_{4}\right)}{\sum_{\mathrm{i}=1}^{\mathrm{n}} \mathrm{P}\left(\mathrm{E} \mid \mathrm{H}_{4}\right)} \frac{0,4}{2} \\
& \mathrm{P}()==0.05 \mathrm{H}_{5} \frac{\mathrm{P}\left(\mathrm{E} \mid \mathrm{H}_{5}\right)}{\sum_{\mathrm{i}=1}^{\mathrm{n}} \mathrm{P}\left(\mathrm{E} \mid \mathrm{H}_{5}\right)} \frac{0,1}{2} \\
& \mathrm{P}()==0.15 \mathrm{H}_{6} \frac{\mathrm{P}\left(\mathrm{E} \mid \mathrm{H}_{2}\right)}{\sum_{\mathrm{i}=1}^{\mathrm{n}} \mathrm{P}\left(\mathrm{E} \mid \mathrm{H}_{2}\right)} \frac{0,3}{2} \\
& \mathrm{P}()==0.05 \mathrm{H}_{7} \frac{\mathrm{P}\left(\mathrm{E} \mid \mathrm{H}_{2}\right)}{\sum_{\mathrm{i}=1}^{\mathrm{n}} \mathrm{P}\left(\mathrm{E} \mid \mathrm{H}_{2}\right)} \frac{0,1}{2}
\end{aligned}
$$

After getting the $\mathrm{P}$ value () for the probability of the hypothesis $\mathrm{H}$ regardless of any evidence, the next step is to calculate the probability value for evidence $\mathrm{E}$, which is as follows: $\mathrm{H}_{\mathrm{i}}$

$$
\begin{aligned}
& \sum_{i=1}^{n}=\mathrm{P}(\mathrm{Hi}) * \mathrm{P}(\mathrm{E} \mid \mathrm{Hi}) \\
= & \mathrm{P}(\mathrm{H} 1) * \mathrm{P}(\mathrm{E} \mid \mathrm{H} 1)+\mathrm{P}(\mathrm{H} 2) * \mathrm{P}(\mathrm{E} \mid \mathrm{H} 2)+\mathrm{P}(\mathrm{H} 3) * \mathrm{P}(\mathrm{E} \mid \mathrm{H} 3)+\mathrm{P}(\mathrm{H} 4) * \mathrm{P}(\mathrm{E} \mid \mathrm{H} 4)+\mathrm{P}(\mathrm{H} 5) * \mathrm{P}(\mathrm{E} \mid \mathrm{H} 5)+\mathrm{P} \\
& (\mathrm{H} 6) * \mathrm{P}(\mathrm{E} \mid \mathrm{H} 6)+\mathrm{P}(\mathrm{H} 7) * \mathrm{P}(\mathrm{E} \mid \mathrm{H} 7) \\
= & (0.05 * 0.1)+(0.2 * 0.4)+(0.3 * 0.6)+(0.2 * 0.4)+(0.05 * 0.1)+(0.15 * 0.3)+(0.05 * 0.1) \\
= & 0.005+0.08+0.18+0.08+0.005+0.045+0.005 \\
= & 0.4
\end{aligned}
$$

After getting the value, the next step is to calculate the Bayes value for each hypothesis:

$$
\begin{aligned}
& \mathrm{P}(\mathrm{H} 1 \mid \mathrm{E})=0.0125 \frac{0,1 * 0,05}{0,4} \\
& \mathrm{P}(\mathrm{H} 2 \mid \mathrm{E})=0.2 \frac{0,4 * 0,2}{0,4} \\
& \mathrm{P}(\mathrm{H} 3 \mid \mathrm{E})=0.45 \frac{0,6 * 0,3}{0,4} \\
& \mathrm{P}(\mathrm{H} 4 \mid \mathrm{E})==0.2 \frac{0,4 * 0,2}{0,4} \\
& \mathrm{P}(\mathrm{H} 5 \mid \mathrm{E})=0.0125 \frac{0,1 * 0,05}{0,4} \\
& \mathrm{P}(\mathrm{H} 6 \mid \mathrm{E})=0.1125 \frac{0,3 * 0,15}{0,4} \\
& \mathrm{P}(\mathrm{H} 7 \mid \mathrm{E})=0.0125 \frac{0,1 * 0,05}{0,4}
\end{aligned}
$$

After getting all the $\mathrm{P}$ values $(\mathrm{Hi} \mid \mathrm{E})$, the next step is to calculate the total value of the Bayes: 


$$
\begin{aligned}
\sum_{i=1}^{n} \text { Bayes }= & \text { Bayes } 1+\text { Bayes } 2+\text { Bayes } 3+\text { Bayes } 4+\text { Bayes } 5+\text { Bayes } 6+\text { Bayes } 7 \\
= & (0.1 * 0.0125)+(0.4 * 0.2)+(0.6 * 0.45)+(0.4 * 0.2)+(0.1 * 0.0125)+(0.3 * \\
& 0.1125)+(0.1 * 0.0125) \\
= & (0.00125+0.08+0.27+0.08+0.00125+0.03375+0.00125) \\
= & 0.4675
\end{aligned}
$$

The final step is to calculate the percentage of the total value of the bayes:

Percentage $=0.4675 * 100 \%=46.75 \%$.

From the results of calculations with the symptoms that exist, the toddler is experiencing Ear Infection with a percentage value of $46.75 \%$

\section{DISCUSSION}

Based on the results of the study it was shown that valid patients were about $46 \%$, smaller than the study ((Murni \& Riandari, 2018)) which is about $75.6 \%$. Thus, it is concluded that the selection of symptom values is based on the instinct of the patient who experiences the next one and is calculated by the Bayesian formula.

\section{CONCLUSION}

The expert system for identifying diseases of children under five by applying the Bayes theorema method can overcome problems in determining the types of diseases of children under five based on the symptoms experienced. This can take action early to treat diseases of toddlers that are experienced. The method of the bayaes theorem can be a solution to solving problems in identifying diseases of children under five.

\section{REFERENCE}

Aini, N., Ramadiani, R., \& Hatta, HR (2017). Expert System for Tuberculosis Diagnosis. Mulawarman Informatics: Scientific Journal of Computer Science. https://doi.org/10.30872/jim.v12i1.224

Aji, AH, Furqon, MT, \& Widodo, AW (2018). Expert System for Diagnosing Pregnant Women Diseases Using the Certainty Factor (CF) Method. Journal of Information Technology and Computer Science Development, 2 (5), 2127-2134. http://j-ptiik.ub.ac.id/index.php/j-ptiik/article/view/1556

Dewi, PS, Lestari, RD, \& Lestari, RT (2015). KOI FISH DISEASE DIAGNOSIS SYSTEM WITH BAYES METHOD. Komputa: Journal of Computer Science and Informatics. https://doi.org/10.34010/komputa.v4i1.2404

Fricles Ariwisanto Sianturi. (2019). Bayes theorem analysis method in diagnosing miscarriage in pregnant women based on type of food Information and Computer Engineering (Tekinkom), 2 (1), 87-92. http://jurnal.murnisadar.ac.id/index.php/Tekinkom/article/view/78

Gunawan, EP, \& Wardoyo, R. (2018). An Expert System Using Certainty Factor for Determining Insomnia Acupoint. IJCCS (Indonesian Journal of Computing and Cybernetics Systems), 12 (2), 119. https://doi.org/10.22146/ijccs.26328

Harijanto, B., \& Latif, RA (2016). DISEASE DIAGNOSIS EXPERT SYSTEM IN CATS USING ANDROID BASED BAYES THEOREME METHOD. Journal of Polinema Informatics. https://doi.org/10.33795/jip.v2i4.79

Murni, S., \& Riandari, F. (2018). Application of the Bayes Theorem Method to the Expert System to Diagnose Gastric Disease. Prima Journal of Technology and Computer Science (JUTIKOMP). https://doi.org/10.34012/jutikomp.v1i2.226

Muslim, AA et al. (2015). Expert System for Diagnosis of Pests and Diseases of Chili Based on Bayes Theorem. Millionaire.

Pramudia, H., \& Nugroho, A. (2017). Laptop Damage Information System Using Naïve Bayes Method. Electrical Technology, Mercu Buana University.

Ramadhan, PS (2018). Expert System for Diagnosing Immune Dermatitis Using Bayes Theorem. InfoTekJar (National Journal of Informatics and Network Technology). https://doi.org/10.30743/infotekjar.v3i1.643

Ramadan, PS (2019). Application of Comparison of Bayes' Theorem with Euclidean Probability in Dermatic Bacterial Diagnosis. InfoTekJar (National Journal of Informatics and Network Technology). https://doi.org/10.30743/infotekjar.v4i1.1579

Ramadan, PS, \& Pane, UFS (2018). Comparative Analysis of Methods (Certainty Factor, Dempster Shafer and Bayes Theorem) to Diagnose Inflammatory Dermatitis in Children. SAINTIKOM Journal (Journal of Information Management and Computer Science).

Sasangka, B., \& Witanti, A. (2019). Expert System for Diagnosing Acute Respiratory Infectious Diseases in Children Using Bayes's Theorem. JMAI (Journal of Multimedia \& Artificial Intelligence). 
https://doi.org/10.26486/jmai.v3i2.83

Sianturi, FA (2019). Implementation of the Certainty Factor Method for Diagnosing Computer Damage. MEANS (Media Information Analysis and Systems), 4 (2), 176-184.

Sinaga, B., Hasugian, PM, \& Manurung, AM (2018). Expert System to Diagnose Smartphone Damage. 3 (1), $333-339$

Syahputra, T., Dahria, M., \& Putri, PD (2017). Expert System To Diagnose Anemia Using Bayes Theorem Method. SAINTIKOM Journal. 